\title{
Comparison between single port videolaparoscopy and miniceliotomy with snock hook ovariohysterectomy techniques in bitches
}

\author{
Alexandre José Coutinho ${ }^{1}$ Beatriz Gasser $^{1}$ Mariana Garcia Kako Rodriguez $^{1}$ (8) \\ Ricardo Andres Ramirez Uscategui ${ }^{2 *}, 3$ Victor José Correia Santos ${ }^{1} \odot$ Caio de Faria Tiosso ${ }^{3}$ \\ Felipe Farias Pereira da Câmara Barros ${ }^{4}$ Gilson Hélio Toniollo ${ }^{1}$
}

\footnotetext{
${ }^{1}$ Departamento de Medicina Veterinária Preventiva e Reprodução Animal, Universidade Estadual Paulista (Unesp), Jaboticabal, SP, Brasil. ${ }^{2}$ Instituto de Ciências Agrarias, Universidade Federal dos Vales do Jequitinhonha e Mucuri (UFVJM), Unaí, MG, Brasil. E-mail: ricardo.uscategui@ufvjm.edu.br. "Corresponding author.

${ }^{3}$ Departamento de Clínica e Cirurgia Veterinária, Universidade Estadual Paulista (Unesp), Jaboticabal, SP, Brasil.

${ }^{4}$ Instituto de Veterinária, Universidade Federal Rural do Rio do Janeiro (UFRRJ), Seropédica, RJ, Brasil.
}

\begin{abstract}
In order to use and study minimally invasive techniques to reduce side effects of ovarian-hysterectomy (OHE) in bitches, the aim of this study was to compare time, surgical complications, pain and postoperative inflammatory response, caused by single port videolaparoscopic OHE and traditional miniceliotomy with snook hook. Twenty-four healthy bitches were randomly divided in two groups: videolaparoscopy (Video) and miniceliotomy (MiniLap). Surgical time and complications, pain, need for analgesic rescue, C-reactive protein concentration, glycaemia and voluntary food ingestion were evaluated during 24 hours following the procedure and compared statistically. Surgical time (38 $7 \mathrm{~min})$, surgical complications $(17 \%)$, postoperative pain intensity, need for analgesic rescue and C-reactive protein concentration were similar between groups $(P>0.05)$. Glycaemia was lower in Video group $(P=0.03)$, animals fed faster and in greater proportion $(P=0.02)$. Thus, it is concluded that both OHE techniques result in similar complications, surgical time and inflammatory response; however, animals on Video group fed more readily and presented lower glycaemia, which point to lower stress levels. These findings validated the indication of this technique.
\end{abstract}

Key words: videosurgery, C-reactive protein, glycaemia, postoperative pain, surgical complications.

\section{Comparação das técnicas videolaparoscópica com único portal e miniceliotomia com gancho de Snook para ovário-histerectomia em cadelas}

RESUMO: Com o intuito de utilizar e estudar técnicas minimamente invasivas que permitam reduzir os efeitos adversos da ováriohisterectomia $(\mathrm{OVH})$ em cadelas objetivou-se comparar: o tempo, as complicações cirúrgicas, a dor e a resposta inflamatória pós-operatória, resultantes da OVH laparoscópica por único portal e a miniceliotomia tradicional com gancho de Snook. Vinte e quatro cadelas hígidas foram aleatoriamente divididas em dois grupos e realizadas a OVH por videolaparoscopia (Video) ou miniceliotomia (MiniLap). Avaliaramse e compararam-se estatisticamente: o tempo e intercorrências cirúrgicas, a dor, necessidade de resgate analgésico, concentração sérica de proteina $C$ reativa, glicemia e o consumo voluntário de alimento durante as 24 horas subsequentes ao procedimento. O tempo operatório (38 7 min), as intercorrências cirúrgicas (17\%), a intensidade de dor pós-operatória, a necessidade de resgate analgésico e a concentração sérica de proteina $C$ reativa foram similares entre os grupos $(P>0,05)$. A glicemia foi menor nos animais do grupo Video $(P=0,03)$ e estes se alimentaram mais rapidamente e em maior proporção $(P=0,02)$. Assim, conclui-se que as técnicas de OVH por videolaparoscopia, miniceliotomia resultam em complicações, tempos cirúrgicos e respostas inflamatórias similares, no entanto, os animais submetidos à videolaparoscopia se alimentam mais prontamente e apresentam menor índice glicêmico indicando um nivel de estresse menor e este resultado considera-se válido para a indicação desta técnica.

Palavras-chave: vídeocirurgia, proteína C reativa, glicemia, dor pós-operatória, complicações cirúrgicas.

\section{INTRODUCTION}

Ovarian-hysterectomy (OHE) is the keystone of canine population control, that is a public health problem, also prevents the effects of estrus, avoids and treat genital tract diseases and reduces mammary neoplasms incidence (SORENMO et al., 2000; SPAIN et al., 2004). However, as any surgical procedure, complications such as hemorrhage, pain, infection, hernia, evisceration, adhesions formation and other postoperative morbidities may occur (COOLMAN et al., 1999; HANCOCK et al., 2005).

The occurrence of pain and inflammation in post-surgical period adds significant time to recovery, causes delay in healing, suppresses immunological profile, impairs body homeostasis and increases metabolism and catabolism (OTERO, 2005). In order to reduce these undesirable effects, minimally 
invasive techniques such as laparo-endoscopic singlesite surgery (LESS) have been developed and present promising results for canine OHE. Since this technique do not increase operative time, complications rate and the limited number of skin incisions provides less tissues trauma, reduces contamination and postoperative discomfort and hospitalization time (MALM, 2004; KHALAJ et al., 2012).

Considering these precepts, we aimed to compare surgical time, complications, pain, stress and postoperative inflammatory response after OHE performed by single port videolaparoscopic technique or traditional minilaparotomy using Snook hook in bitches.

\section{MATERIALS AND METHODS}

Twenty-four non-neutered bitches were included, aging between 1 and 6 years and weighting 5.0 to $15.0 \mathrm{~kg}$, these animals came from animal protection association of Taquaritinga, São Paulo. Only healthy and anestrous bitches were chosen, after general clinical evaluation, colpo-cytological examination, abdominal ultrasonography, blood count, serum creatinine and alanine amino transferase dosage. The animals were randomly assigned in two experimental groups, named: Video $(n=12)$ and MiniLap $(n=12)$, according to the surgical technic to be performed. Surgical team was the same in all procedures.

Animals were kept in individual kennels from the previous day until 24 hours after the procedure and were food-fasted for 12 hours and water-fasted for six hours. Patients received intramuscular injection of chlorpromazine $(0.5 \mathrm{mg} / \mathrm{kg})$ and morphine $(0.5 \mathrm{mg} / \mathrm{kg})$ as pre-anesthetic medication. After 20 minutes, extensive abdominal tricotomy and cephalic vein catheterization were performed and intravenous fluid therapy (Ringer Lactate $5 \mathrm{ml} / \mathrm{kg} / \mathrm{h}$ ) was initiated. Subsequently, anesthesia was induced with intravenous propofol at the dose required to enable orotracheal intubation with a Magil probe of appropriate diameter. Anesthesia maintenance was made with isoflurane vaporized in $100 \%$ oxygen in a circular anesthetic circuit in the minimum concentration required to maintain surgical anesthetic plane $(\mathrm{MAP}>60 \mathrm{mmHg}$, ventral ocular rotation, and lack of protective reflexes and painful motor response), physiological functions was monitored (heart and respiratory rate, invasive blood pressure, peripheral oxygen saturation, body temperature and $\mathrm{CO}_{2}$ concentration at the end of expiration) with the aid of a multiparametric monitor (DX2023 ${ }^{\circledR}$, Dixtal, Brazil).
The bitches were placed in dorsal recumbency and urinary bladder was catheterized and emptied. Skin surgical asepsis was performed with $2 \%$ chlorhexidine gluconate and $70 \%$ ethyl alcohol. The procedure started when authorized by the anesthetic team.

According to the experimental group, in the Video group, a single videolaparoscopic approach was established in the median prepubic region, using a small cutaneous incision for insertion of $11 \mathrm{~mm}$ trocar, according to BRUN et al. (2011). After trocar insertion the abdomen was inflated with $\mathrm{CO}_{2}$, in a flow of $1-2 \mathrm{~L} / \mathrm{min}$ and intra-abdominal pressure of $10 \mathrm{mmHg}$. Initially, a general abdominal cavity exploration was carried out with $10 \mathrm{~mm}$ videolaparoscopic optic and provided with a $5 \mathrm{~mm}$ working channel and zerodegree instruments (Model 26038 AA - Karl Storz, Germany). Animals were slightly rotated to the left recumbency and the right ovarian arteriovenous complex (OAC) was manipulated using a $42 \mathrm{~cm}$ videolaparoscopic Babcock clamping forceps, the uterine ligament was suspended to the inner surface of the right ventral abdominal wall and attached to it by transparietal nylon suture $\left(\mathrm{n}^{\circ} 0\right)$, according to DEVITT et al. (2005).

The right OAC was then submitted to coagulation and section with bipolarvideolaparoscopic clamp with simultaneous coagulation and shearing (Powerblade $^{\circledR}$ - WEM Equipamentos Eletrônicos, Brazil), introduced through the optic's working channel and coupled to the electrocoagulation generator (40 watts). After resection, the pedicle was inspected for hemostasis and the suture was removed. Afterwards, animals were slightly rotated to the right side and the same procedures were performed in the left OAC. The left ovary was then apprehended and drawn into the trocar and gently withdrawn to the outside of the abdominal cavity exposing the uterine bifurcation. Subsequently, the uterine body was transfixed with poliglecaprone $25\left(\mathrm{n}^{\circ} 0\right)$ and resected. The uterine cervix was then repositioned into the abdominal cavity, followed by drainage of the residual pneumoperitoneum by light manual compression of the abdomen.

Suture of the rectus abdominis muscle was performed using a Sultan pattern, with poliglecaprone $25\left(\mathrm{n}^{\circ} 0\right)$ and dermorrhaphy with Wolf pattern, using nylon $\left(n^{\circ} 3 / 0\right)$. Main steps of this process are shown in figure 1.

In the MiniLap group, a $3 \mathrm{~cm}$ celiotomy incision was performed on the midline of the retroumbilical region, beginning about one centimeter caudal to the umbilical scar. The right uterine horn 


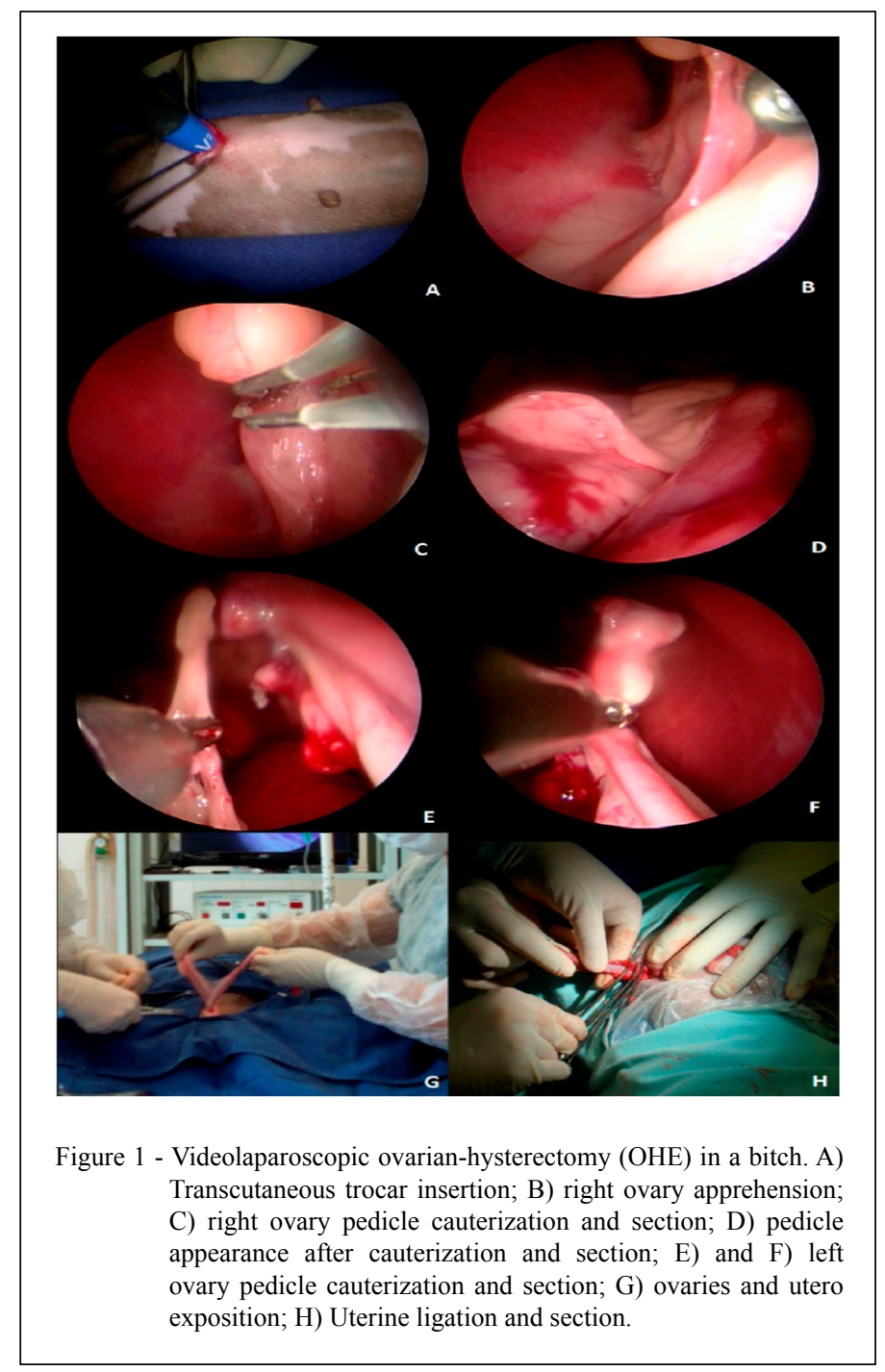

was drawn and externalized with snook hook until visualization of the right $\mathrm{OAC}$, then the right ovary suspensor ligament was sectioned and preventive hemostasis of the pedicle performed by transfixing it, with a surgeon's knot using poliglecaprone $25\left(\mathrm{n}^{\circ} 0\right)$ and sectioning it, between ligation and ovary. The same procedures were performed for the left OAC removed from the cavity by gentle traction of the right horn. In the uterine cervix, transfixation with a Miller's knot and excision were performed.

The uterine cervix was repositioned in the abdominal cavity and, after final inspection, abdominal musculature suture was performed with poliglecaprone $25\left(\mathrm{n}^{\circ} 0\right)$ in an interrupted Sultan pattern, reduction of dead space with subcutaneous suture in the Cushing pattern with poliglecaprone $\left(n^{\circ} 3 / 0\right)$ and skin stitching with simple stitches in Wolf pattern with nylon (n³/0).

After the procedures, the supply of inhaled anesthetic was stopped, and a local dressing was applied with sterile gauze covered by micropore surgical tape, and a garment was placed to protect the wound and impedes the visualization of this by evaluators. Once the laryngeal reflex was recovered, the animals were extubated and as soon as they recovered the walking ability, were conducted to the individual kennel, commercial ration and water were served ad libitum until the end of the experimental period.

The time between the initial incision and the end of the dermorrhaphy was considered the surgical time in minutes, if any type of surgical intercurrence occurred during this interval, 
the procedure was converted to an exploratory celiotomy, the complication was recorded and the animal removed from the postoperative evaluation.

During the postoperative period, pain was assessed by applying the pain scales of the University of Melbourne and the visual analogue scale (VAS) by two trained and blinded evaluators, as soon as the animal regained walking ability and $0.5 ; 1 ; 2 ; 4 ; 8 ; 12$; 16 and 24 hours later. If the pain scale of the University of Melbourne resulted in values greater than 12 and/ or VAS $>50 \mathrm{~mm}$ the animals received rescue analgesia with tramadol hydrochloride $4 \mathrm{mg} / \mathrm{kg}$ IV.

Blood collection $(3 \mathrm{ml})$ were made from the jugular vein, immediately before the pre-anesthetic medication and 1, 4, 12 and 24 hours after the end of the surgical procedure for blood glucose concentration measurement by portable glucometer (Accu-Chek ${ }^{\circledR}$ Roche Diagnostics, Brazil) and serum concentrations of C-reactive protein dosage by chemiluminescence (HSC PCR ${ }^{\circledR}$ Kit - Siemens, Germany). And at the same time, voluntary food ingestion was assessed by direct observation during 24 hours postoperative period.

At the end of the evaluation period, all patients received subcutaneous (SC) meloxicam $(0.2 \mathrm{mg} / \mathrm{kg})$ and tramadol hydrochloride $(4 \mathrm{mg} / \mathrm{kg})$ and the owner of the animals gave $25 \mathrm{mg} / \mathrm{kg}$ of oral dipyrone every 8 hours for 5 days.

Age, body weight and surgical time were compared between groups by Student's t-test.
Complications by Fisher's exact test. Glycaemia and C-reactive protein by analysis of variance (ANOVA), using the completely randomized design with repeated measures and Tukey post-test. The pain scores were compared by the Kruskal-Wallis test and the Dunns post-test. The need for analgesic rescue and voluntary food consumption over time was compared, by Kaplan Meier's survival method. These procedures were performed using the software Minitab $16^{\circledR}$ and significance set at $5 \%(\mathrm{P}<0.05)$.

\section{RESULTS}

The mean age of the animals was $2.4 \pm 1.0$ years and the mean weight was $9.2 \pm 2.5 \mathrm{~kg}$. Surgical time was $41.1 \pm 5.9 \mathrm{~min}$ for the Video group and $35.1 \pm 7.1 \mathrm{~min}$ for the MiniLap group (Figure 2), these results were considered similar $(\mathrm{P}>0.05)$.

During surgical procedures were intraoperative complications in $17 \%$ of the cases (4/24). Two animals of the Video group presented hemorrhage and required conversion, one of them due to splenic perforation during trocar insertion and the other one by profuse bleeding of the ovarian pedicle, which made impossible visualization and manipulation of the surgical region. In the MiniLap group, one patient presented diffuse bleeding of the ovarian pedicles and uterine cervix and in the other case occurred the accidental loss the ovarian pedicle.

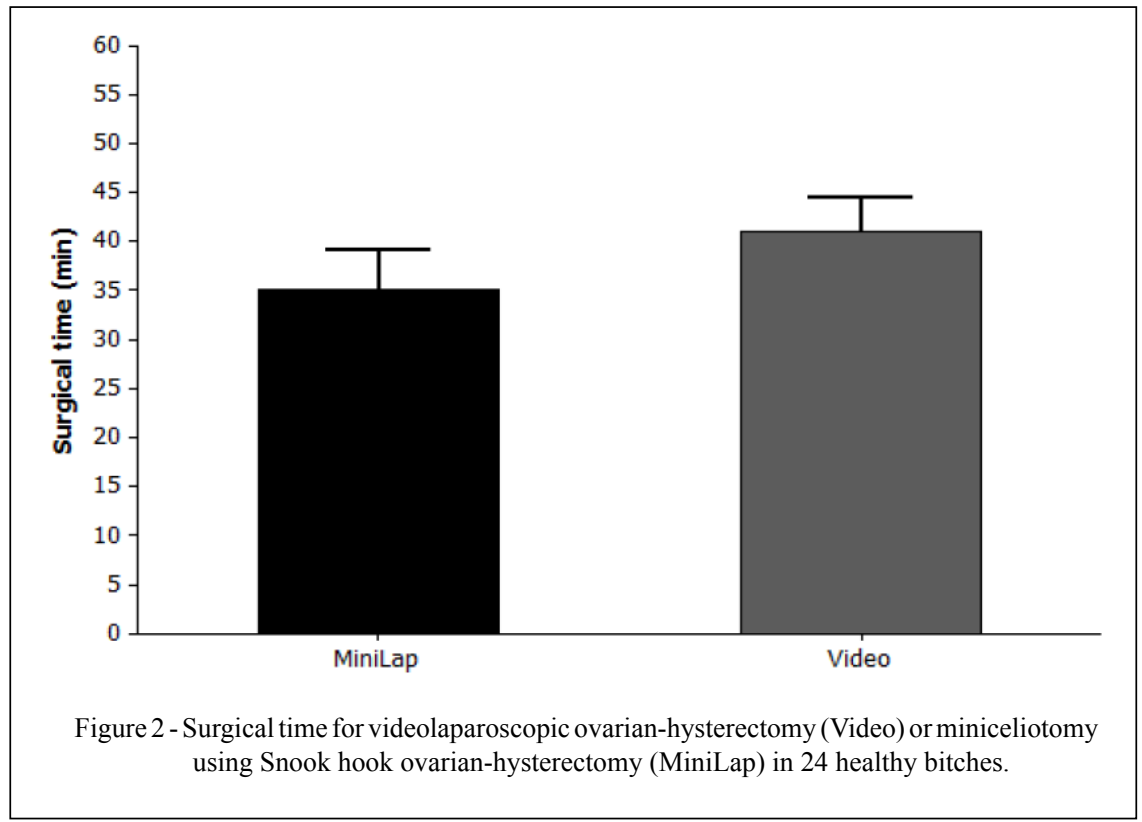

Ciência Rural, v.48, n.10, 2018. 
Complications were not correlated with the surgical technique employed $(\mathrm{P}=0.99)$ and were successfully treated to ensure patients survival. It is important to note that despite these surgical intercurrences, the animals did not present sympathomimetic hemodynamic changes that indicate nociceptive signs during the intraoperative period.

Intensity of postoperative pain assessed by Melborne and VAS pain scales (Figure 3) was similar in both groups $(\mathrm{P}>0.05)$. Conversely, these scores declined gradually from the $12^{\text {th }}$ hour after procedures until the end of the experimental period $(\mathrm{p}=0.02)$ and a positive correlation $(\mathrm{r}=0.72)$ was found between scales $(\mathrm{P}<0.01)$.

In Video group, $1 / 10$ bitches required postoperative analgesic rescue, while in MiniLap group 2/10 (Figure 4); however, these results did not present statistical difference $(\mathrm{P}>0.05)$.

Serum concentration of C-reactive protein (Figure 5) was similar between groups and evaluated periods $(\mathrm{P}>0.05)$. Glycaemia (Figure 5) was lower in the Video group when compared to MiniLap group $(\mathrm{P}=0.03)$, from the first hour of evaluation until the end of the experimental period. In both groups, glycaemia was higher $(\mathrm{P}=0.04)$ in the first hour than in moments 0,12 and 24 hours. Animals of Video group fed faster and in greater proportion $(\mathrm{P}=0.02)$ than animals of MiniLap group (Figure 4).

\section{DISCUSSION}

Surgical times were similar between groups, as observed in previous studies (DAVIDSON et al 2004, MALM et al. 2004). However, it disagrees with SILVA et al. (2011) who affirms that video OHE technique was faster than conventional technique.

Videolaparoscopic modality proved to be as safe and effective as mini laparotomy since it achieved its therapeutic goal with similar surgical complications rate. In the video group one of the major technical difficulties was the trocar introduction, an at this stage in one bitch the spleen was perforated, and severe hemorrhage occurred, requiring emergency transformation of the technique, this intercurrence reinforces the assertions of BRUN et al. (2000). MALM et al. (2004 and 2005) compared conventional and videolaparoscopic OHE in bitches, concluding that bleeding is lower in videolaparoscopic procedure and coming mainly from visceral punctures, as evidenced in our study.

One animal from the Video group and one from the MiniLap group presented profuse bleeding
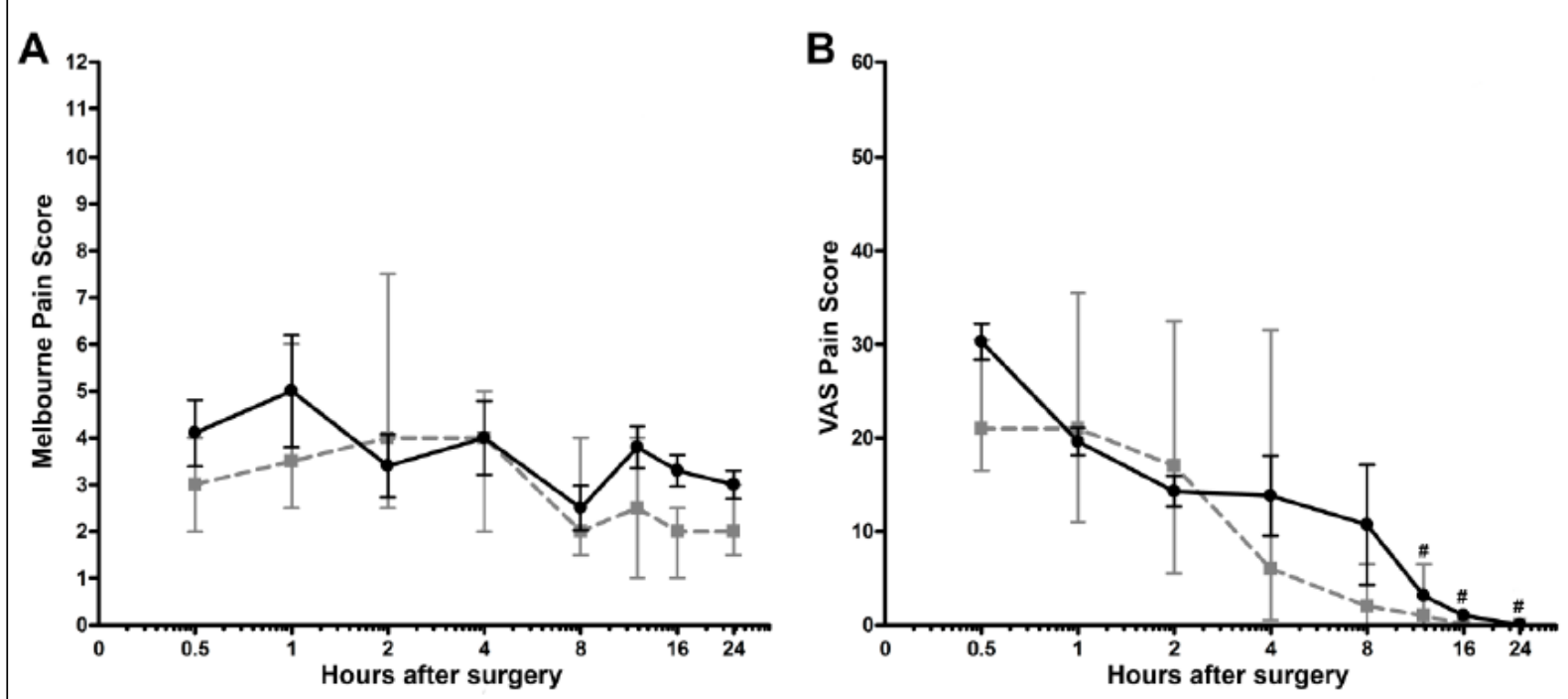

Figure 3 - Median $\pm \mathrm{IQR}$ of: A) Melbourne University pain scale score and B) Vas pain scale score evaluated during the 24h subsequent to anesthetic recovery, in 24 bitches subjected to videolaparoscopic ovarian-hysterectomy (Video, grey broken line with median symbol) or miniceliotomy using Snook hook ovarian-hysterectomy (MiniLap, black line with • median symbol). \#indicate difference $(\mathrm{P}<0,05)$ with precedent moments. 

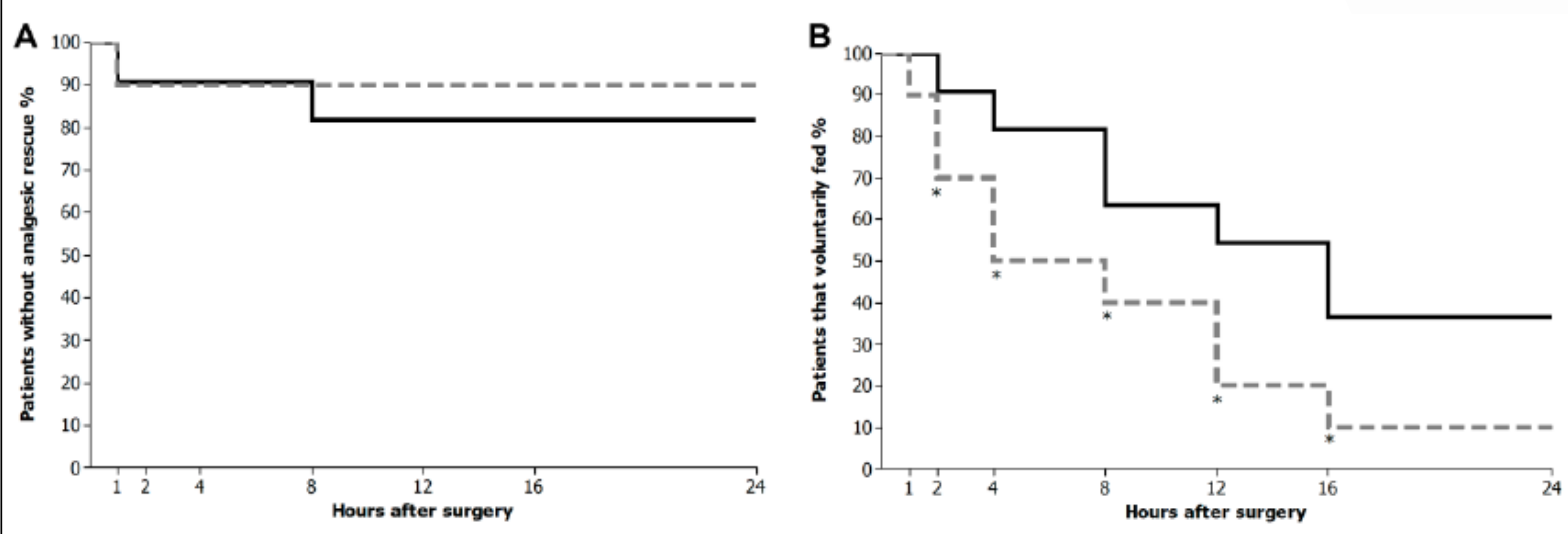

Figure 4 - Kaplan Meier survival curves for A) patient without need of rescue analgesia (\%) and B) patients that voluntary consumed fed (\%); evaluated during the $24 \mathrm{~h}$ subsequent to anesthetic recovery, in 24 bitches subjected to videolaparoscopic ovarianhysterectomy (Video, grey broken line) or miniceliotomy using snook hook ovarian-hysterectomy (MiniLap, black line). *indicate differences $(\mathrm{P}<0,05)$ between treatments.

in the ovarian pedicle, preventing visualization of the surgical field. The OAC hemorrhages are one of the most frequent complications of OHE, which are directly related to the accumulation of adipose tissue in the pedicle of older bitches (VAN GOETHEM et al, 2003). Results of SOUZA et al. (2014) corroborated our results, describing similar bleeding between conventional and videolaparoscopic techniques. Accidental loss of the ovarian pedicle occurred in one bitch of the MiniLap group. During OHE performed by any technique, episodes of mild bleeding from OACs and uterine vessels may occur either using bipolar diathermy (SILVA et al., 2011), Roeder's sliding knot ligation (MALM et al., 2004 and 2005) or hemostatic clips (GUEDES et al., 2012) or even employing more accurate vascular coagulation systems, such as the ultrasonic energy of the harmonic scalpel (HANCOCK et al., 2005).

Postoperative pain evaluation scales showed no difference between groups and followed the expected behavior in patients submitted to these procedures, being pain reduced gradually in the first 24 hours. Although there was a need to rescue in two animals of the MiniLap group and only one of the Video group, this result was statistically similar. However, the animals of the Video group fed voluntarily earlier and in greater proportion than those in MiniLap group, and this result is considered a beneficial and important clinical factor since it demonstrates better postoperative comfort and probably indicates a faster recovery. Postoperative food ingestion has already been used as an indicator of postoperative well-being in dogs undergoing surgical procedures (SARRAU et al., 2007).

DAVIDSON et al. (2004), DEVITT et al. (2005), HANCOCK et al. (2005) and SILVA et al. (2011) reported less postoperative discomfort in the videolaparoscopic approach, similar to our results. However, it is emphasized that these authors used conventional technique, while we used miniceliotomy technique. Conversely, it is expected that food consumption will increase glycemic levels, but this correlation was not reported in our study. These finding denotes that animals of the MiniLap group probably suffered a higher stress levels, since according to $\mathrm{KO}$ et al. (2000), the increase in glycaemia after surgical procedure results from nociceptive sensitization. These results are similar to those reported by RANGANATH \& KUMAR (2007) who reported higher glycaemia values in animals submitted to miniceliotomy when compared to celiotomy.

Patients in pain have high levels of circulating catecholamine, aldosterone and cortisol, leading to hyperglycemia (FOX et al., 1994). These patients delay in feeding correctly, predisposing them to body weight loss, protein catabolism and self-mutilation (OTERO, 2005). It may indicate that animals from MiniLap group showed the metabolic consequences of pain without clinical demonstrating of this phenomenon, perhaps, due to moderate pain and their ability to deal with it (MATHEWS, 2000). 

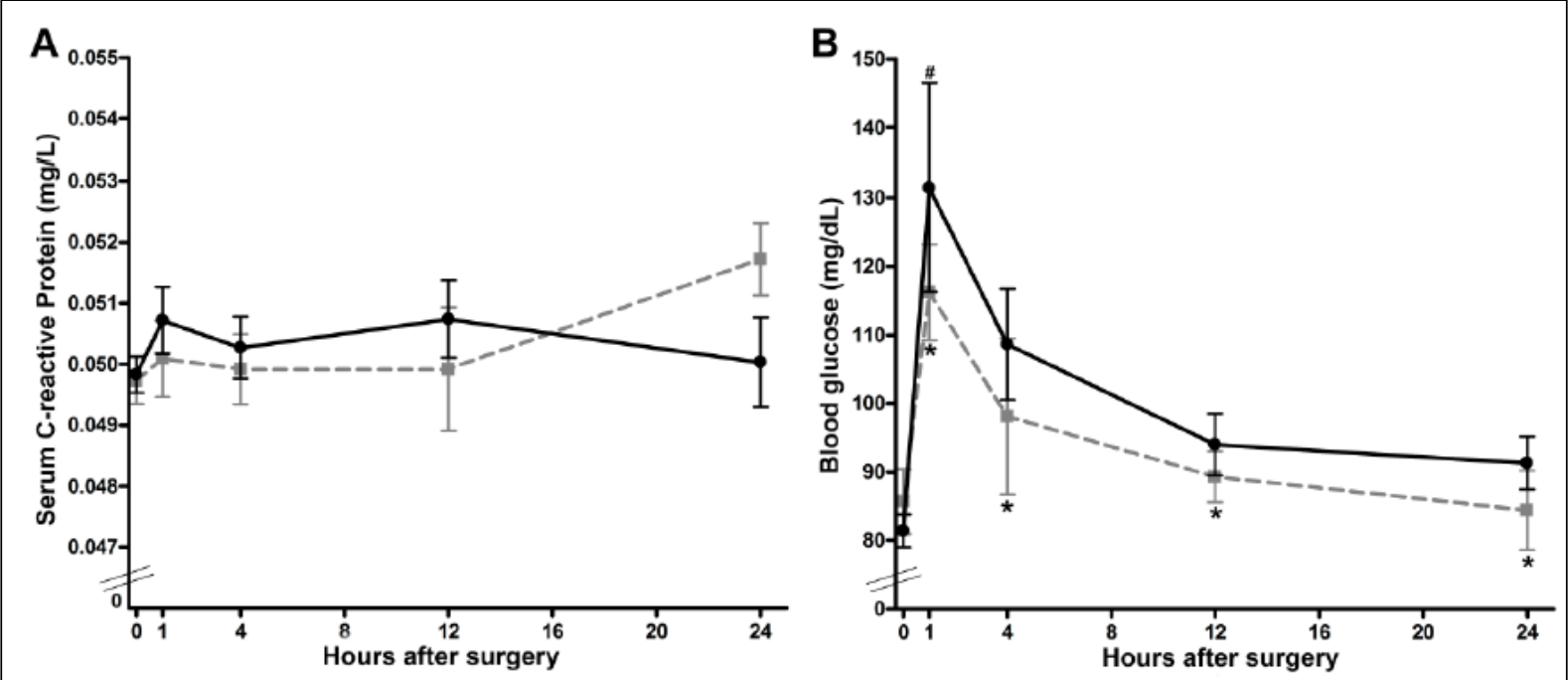

Figure 5 - Mean \pm SD of: A) Serum C-reactive protein (mg/dL) and B) Blood glucose (mg/dL) evaluated during the $24 \mathrm{~h}$ subsequent to anesthetic recovery, in 24 bitches subjected to videolaparoscopic ovarian-hysterectomy (Video, grey broken line with $\mathbf{m e a n}$ symbol) or miniceliotomy using Snook hook ovarian-hysterectomy (MiniLap, black line with • mean symbol). *indicate differences $(\mathrm{P}<0.05)$ between treatments.

Several studies have indicated that C-reactive protein increases immediately after OHE and up to 3 days later (DABROWSKI et al., 2007; ZHANG et al., 2013). RANGANATH \& KUMAR (2007) reported that OHE by videolaparoscopic approach results in significantly lower values of C-reactive protein when compared to the flank miniceliotomy approach. It diverges from our results, since the values of this protein were similar between groups and moments. This difference can be attributed to the dosage technique, since has been reported that tests used to perform the measurement are very different from each other and not all of them are reliable (FRANSSON et al., 2007), which is an important indication to improve the laboratory technique in future studies.

\section{CONCLUSION}

The techniques of OHE by single portal videolaparoscopy and miniceliotomy using snook hook result in similar surgical time, complications and inflammatory responses; however, animals submitted to videolaparoscopy feed more readily and have a lower glycemic index indicating a lower stress levels; therefore, these results are considered valid for the indication of videolaparoscopy technique.

\section{ACKNOWLEDGMENTS}

The authors would like to thank for Coordination for Improvement of Superior Level Personnel (CAPES) for financial support. Also, to Veterinary Hospital "Governor Laudo Natel", for lending, equipment, infrastructure and staff.

\section{COMMITTEE ON ETHICS AND BIOSAFETY}

This study was approved by the Ethics Committee on Animal Use (CEUA), form the Faculdade de Ciências Agrárias e Veterinárias (FCAV) of the Universidade Estadual Paulista Jaboticabal (Unesp) by protocol number 019770/12.

\section{DECLARATION OF CONFLICTING OF INTERESTS}

The authors declare no conflict of interest. The founding sponsors had no role in the design of the study; in the collection, analyses, or interpretation of data; in the writing of the manuscript, and in the decision to publish the results.

\section{AUTHOR'S CONTRIBUTIONS}

All authors contributed equally for the conception and writing of the manuscript. All authors critically revised the manuscript and approved of the final version.

\section{REFERENCES}

BRUN, M.V. et al. Laparoscopic ovariohysterectomy in canine. Brazilian Journal of Veterinary Research and Animal Science, 
v.37, n.6, 2000. Available from: <http://dx.doi.org/10.1590/S141395962000000600011>. Accessed: Sept. 18, 2017. doi: 10.1590/ S1413-95962000000600011.

BRUN, M.V. et al. Ovariohysterectomy in a dog by hybrid NOTES technique - a case report. Canadian Veterinary Journal, v.52, p.637-640, 2011. Available from: <https://www.ncbi.nlm.nih.gov/ pmc/articles/PMC3095161/>. Accessed: Sept. 18, 2017.

FRANSSON, B. A.; et al. Assessment of three automated assays for C-reactive protein determination in dogs. American journal of veterinary research, v.68, n.12, p.1281-1286, 2007. Available from: <https://doi.org/10.2460/ajvr.68.12.1281>. Accessed: Sept. 18, 2017. doi: 10.2460/ajvr.68.12.1281.

COOLMAN, B. R. et al. Partial colonic obstruction following ovariohysterectomy: a report of three cases. Journal of the American Animal Hospital Association, Stanford, v.35, n.2, p.169-172, 1999. Available from: <https://doi. org/10.5326/15473317-35-2-169>. Accessed: Sept. 18, 2017. doi: $10.5326 / 15473317-35-2-169$

DABROWSKI, R. et al. Changes in CRP, SAA and haptoglobin produced in response to ovariohysterectomy in healthy bitches and those with piometra. Theriogenology, v.67, p.321-327, 2007. Available from: <https://doi.org/10.1016/j. theriogenology.2006.07.019>. Accessed: Sept. 18, 2017. doi: 10.1016/j.theriogenology.2006.07.019.

DAVIDSON, E.B. et al. Comparision of Laparoscopic Ovariohysterectomy and Ovariohysterectomy in Dogs. Veterinary Surgery, v.33, p.62-69, 2004. Available from: <https://doi. org/10.1111/j.1532-950X.2004.04003.x>. Accessed: Sept. 18, 2017. doi: 10.1111/j.1532-950X.2004.04003.x.

DEVITT, C.M. et al. Duration, complications, stress, and pain of open ovariohysterectomy versus a simple method of laparoscopic assisted ovariohysterectomy in dogs. Journal of the American Veterinary Medical Association, v.227, n.6, p.921-927, set, 2005. Available from: <https://doi.org/10.2460/ javma.2005.227.921>. Accessed: Sept. 18, 2017. doi: 10.2460/ javma.2005.227.921

FOX, S. M. et al. Changes in plasma cortisol concentrations before, during and after analgesia, anesthesia and anesthesia plus ovariohysterectomy in bitches. Research in Veterinary Science, v.57, p.110-8, 1994. Available from: $<$ https://doi.org/10.1016/00345288(94)90091-4>. Accessed: Sept. 18, 2017. doi: 10.1016/00345288(94)90091-4

GUEDES, R. L. et al. Videoassisted ovariohysterectomy with two portals for pyometra's treatment in a bitch. Ciência Rural, v.42, n.6, p.1040-3, 2012. Available from: <http://dx.doi.org/10.1590/ S0103-84782012000600014>. Accessed: Sept. 18, 2017. doi: $10.1590 / \mathrm{S} 0103-84782012000600014$.

HANCOCK, R. B. et al. Comparison of postoperative pain after ovariohysterectomy by harmonic scalpel-assisted laparoscopy compared with median celiotomy and ligation in dogs. Veterinary Surgery, v.34, n.3, p.273-82, 2005. Available from: $<$ https://doi. org/10.1111/j.1532-950x.2005.00041.x>. Accessed: Sept. 18, 2017. doi: 10.1111/j.1532-950x.2005.00041.x.

KHALAJ, A. et al. Comparison between single and three portal laparoscopic splenectomy in dogs. BMC Veterinary Research, v.8, n.161, p.1-4, 2012. Available from: $<$ https://doi. org/10.1186/1746-6148-8-161>. Accessed: Sept. 18, 2017. doi: $10.1186 / 1746-6148-8-161$

KO, J.C. et al. Cardiorespiratory responses and plasma cortisol concentrations in dogs treated with medetomidine before undergoing ovariohysterectomy. Journal of the American Veterinary Medical Association, v.217, p.509-514, 2000. Available from: <https://doi.org/10.2460/javma.2000.217.509>. Accessed: Sept. 18, 2017. doi: 10.2460/javma.2000.217.509.

OTERO, P.E. O Manejo da Dor e a Medicina Veterinária. In: OTERO, P.E. Dor Avaliação e Tratamento em Pequenos Animais. São Caetano do Sul:Interbook, p.2-5, 2005.

MALM, C. et al. Ovariohysterectomy: experimental and comparative study between laparoscopic and conventional approaches. Intra-operative phase. Arquivo Brasileiro de Medicina Veterinária e Zootecnia, v.56, n.4, p.457-466, 2004. Available from: <http://dx.doi.org/10.1590/S010209352004000400006>. Accessed: Sept. 18, 2017. doi: 10.1590/ S0102-09352004000400006.

MALM, C. et al. Ovariohysterectomy: experimental and comparative study between laparoscopic and conventional approaches. II- Post-operative clinical evolution. Arquivo Brasileiro de Medicina Veterinária e Zootecnia, v.57, p.162172, 2005. Available from: <http://dx.doi.org/10.1590/S010209352005000800006>. Accessed: Sept. 18, 2017. doi: 10.1590/ S0102-09352005000800006.

MATHEWS, K.A. Pain assessment and general approach to management. Veterinary clinics of north america: small animal practice, v.30, p.729-755, 2000. Available from: <https://doi. org/10.1016/S0195-5616(08)70004-4>. Accessed: Sept. 18, 2017. doi: 10.1016/S0195-5616(08)70004-4.

RANGANATH, L.; KUMAR. S. S. S. Comparative studies on changes in C-reactiveprotein, serum cortisol, blood glucose and aspartate aminotransferase level following left flank method and laparoscopic method of ovariohysterectomy in bitches. Veterinarski ArhiV, v.77, n.6, p.523-529, 2007. Available from: <https:// hrcak.srce.hr/index.php?show=clanak\&id_clanak_jezik=38396>. Accessed: Sept. 18, 2017.

SARRAU, S. et al. Effects of postoperative ketamine infusion on pain control and feeding behaviour in bitches undergoing Mastectomy. Journal of Small Animal Practice, Oxford, v.48, p.670-676, 2007. Available from: <https://doi.org/10.111 1/j.1748-5827.2007.00362.x>. Accessed: Sept. 18, 2017. doi: 10.1111/j.1748-5827.2007.00362.x

SILVA, M.A.M. et al. Single-port video-assisted ovariohisterectomy in bitches: retrospective study of 20 cases. Ciência Rural, v.41, n.2, p.294-300, 2011. Available from: <http://dx.doi.org/10.1590/ S0103-84782011005000013>. Accessed: Sept. 18, 2017. doi: $10.1590 / \mathrm{S} 0103-84782011005000013$.

SORENMO, K. U. et al. Effect of spaying andtiming of spaying on survival of dogs with mammary carcinoma. Journal of Veterinary Internal Medicine, v.14, p.266-270, 2000. Available from: $<$ https://doi.org/10.1111/j.1939-1676.2000.tb01165.x>. Accessed: Sept. 18, 2017. doi: 10.1111/j.1939-1676.2000.tb01165.x.

SOUZA, F. W. et al. Ovariohysterectomy for videosurgery (hybrid vaginal NOTES), celiotomy or mini-celiotomy in bitches. Ciência Rural, v.44, n.3, p.510-6, 2014. Available from: <http://dx.doi. 
org/10.1590/S0103-84782014000300020>. Accessed: Sept. 18, 2017. doi: 10.1590/S0103-84782014000300020.

SPAIN, C.V. et al. Long-term risks and benefits of early age gonadectomy in dogs. Journal of the American Veterinary Medicine Association, v.224, n.3, p.380-387, 2004. Available from: <https://doi.org/10.2460/javma.2004.224.380>. Accessed: Sept. 18, 2017. doi: 10.2460/javma.2004.224.380.

VAN GOETHEM, B. E. et al. Monopolar versus bipolar electrocoagulation in canine laparoscopic ovariectomy: a nonrandomized, prospective, clinical trial. Veterinary Surgery, v.32, p.464-470, 2003. Available from: <https://doi.org/10.1053/ jvet.2003.50052>. Accessed: Sept. 18, 2017. doi: 10.1053/ jvet.2003.50052.

ZHANG, J. T. et al. Gasless laparoscopic ovariohysterectomy and comparison of serum levels of interleukin- 6 and c-reactive protein after lohe and traditional laparoscopic ovariohysterectomy in bitches. Bulletin of the Veterinary Institute in Pulawy, v.57, p.127-130, 2013. Available from: <https://doi.org/10.2478/bvip-2013-0024>. Accessed: Sept. 18, 2017. doi: 10.2478/bvip-2013-0024 